\title{
TINJAUAN HISTORIS PERJALANAN PANCASILA (SEJAK PENETAPANNYA SEBAGAI DASAR NEGARA HINGGA REFORMASI)
}

\author{
Jeremias Pellokila \\ SMA 1 Atambua \\ jeremias@gmail.com
}

\begin{abstract}
Abstrak
Penelitian ini bertujuan untuk mengetahui sejarah perjalanan Pancasila mulai dari penetapannya sebagai dasar negara hingga reformasi. Metode yang diaplikasikan dalam penelitian ini deskriptif kualititatif. Metode pengumpulan data yang dimanfaatkan dalam penelitian adalah studi dokumentasi dan literatur. Adapun hasil penelitian ini menunjukan, bahwa Pancasila pada masa revolusi kemerdekaan belum berjalan sebagaimana mestinya. Pancasila dalam Konstitusi RIS berbeda sekali dengan nilai-nilai Pancasila yang terkandung pada UUD 1945. Pancasila pada masa Orde Lama sama sekali tidak dilaksanakan, melainkan justru diselewengkan melalui tindakannya. Pancasila di era Orde Baru dimanipulasi dengan berbagai tafsir yang tujuannya untuk menutupi segala kebijakannya yang menyimpang. Pancasila di era reformasi semakin tenggelam oleh hiruk pikuk perkembangan kehidupan politik dan demokrasi di Indonesia yang ditandai dengan kebebasan.
\end{abstract}

Kata Kunci: Perjalanan Pancasila, Dasar Negara, dan Reformasi

\begin{abstract}
This research aims to determine the history of Pancasila's journey from its establishment as the basis of the state to reform. The method applied in this research was descriptive qualitative. Data collection methods used in research were documentation and literature studies. The results of this research indicated that Pancasila during the independence revolution has not been running as it should. Pancasila in the RIS Constitution was very different from the values of Pancasila contained in the 1945 Constitution. Pancasila during the Old Order era was not implemented at all, but instead was perverted through its actions. Pancasila in the New Order era was manipulated with various interpretations aimed at covering up any deviant policies. Pancasila in the reform era was increasingly drowned by the hustle and bustle of the development of political and democratic life in Indonesia which was marked by freedom.
\end{abstract}

Keywords: The Journey of Pancasila, the Foundation of the State, and Reform

\section{PENDAHULUAN}

Pancasila kini semakin dilupakan, tidak hanya oleh masyarakat, tetapi juga dikalangan pemerintah. Seakan-akan posisi Pancasila mulai tergeser dari hati bangsa Indonesia. Jika hal itu sampai terjadi, tidak tertutup peluang bangsa Indonesia akan terombang-ambing. Terlebih lagi dengan pesatnya kemajuan teknologi, imformasi, dan komunikasi yang membawa nilai-nilai asing yang belum tentu selaras dengan kepribadian bangsa.

$$
\text { Di sinilah Pancasila berperan }
$$
sebagai benteng dan pelindung yang menjaga bangsa Indonesia dari ancaman akibat perkembangan iptek. Dengan modal Pancasila, Indonesia dapat dengan mudah melalui berbagai ancaman, tantangan, hambatan dan gangguan (ATHG) (Santika, 2019). Namun untuk dapat mengatasi segala tantangan, ancaman, hambatan, dan gangguan tidaklah mudah. Karena tidak semua rakyat Indonesia paham dengan Pancasila yang merupakan ideologi. 
Jangankan masyarakat awam, terkadang setingkat pejabat pun tidak hapal dengan Pancasila. Kalau sekedar menghapalkan saja sudah tidak mampu bagaimana mungkin bisa memahami makna yang terkandung di dalamnya.

Rendahnya pemahaman bangsa ini terhadap Ideologi Pancasila tidak terlepas dari kelemahan Pendidikan Pancasila yang berlangsung selama ini. Adapun kelemahan paling mendasar yang dapat dilihat dari pendidikan Pancasila adalah terlalu filosofis. Disamping pendekatan Pendidikan Pancasila nya tidaklah kontekstual, tetapi terlampau bersifat teoritis. Hal itulah yang membuat Pancasila semakin sulit dibumikan dalam praktek kehidupan berbangsa dan bernegara. Karena kalau ini dibiarkan berlarut-larut, Pancasila akan semakin tenggelam, ditelan oleh arus globalisasi.

Tidak kalah pentingnya, bahwa kelemahan mendasar dalam pendidikan Pancasila adalah kurangnya pembahasan mengenai sejarah perjalanan Pancasila di Indonesia. Padahal dengan dengan berbekal sejarah perjalanan Pancasila, maka bangsa ini dapat mengetahui kenapa Pancasila masih bertahan sebagai dasar negara Indonesia. Melalui sejarah Pancasila, bangsa Indonesia dapat mengambil makna penting terkait dengan perannya selama ini. tidak mungkin bangsa Indonesia dapat memahami Pancasila secara utuh bila melepaskannya dari konteks sejarah yang melahirkannya.

Dengan sejarah itulah kita dapat menelisik bagaimana perjalanan Pancasila di Indonesia. Dengan begitu Pancasila akan lebih mudah memahaminya. Bahkan bukan hanya sekedar memahami, melainkan juga menggunakan atau mengaktualisasikannya dalam kehidupan berbangsa dan bernegara. Dengan mengetahui perjalanan Pancasila, bangsa Indonesia dapat belajar banyak dan semakin yakin bagaimana saktinya Pancasila dalam menjaga persatuan dan kesatuan. Melalui sejarah perjalanan Pancasila, kita bisa memposisikan dasar negara tersebut dengan benar. Hal itu akan memudahkan rakyat dalam mengamalkan Pancasila.

Berdasarkan latar belakang permasalahan yang peneliti dipaparkan di atas, maka judul yang diangkat dalam artikel ini adalah Tinjauan Historis Perjalanan Pancasila (Sejak Penetapannya Sebagai Dasar Negara Hingga Reformasi).

\section{METODE}

$\begin{array}{rlr} & \text { Metode } & \text { penelitian yang } \\ \text { digunakan dalam penelitian ini adalah }\end{array}$ deskriptif kualitatif. Penelitian deskriptif kualitatif berusaha menggambarkan suatu gejala sosial yang tertuju pada pemecahan masalah di masa sekarang dan mendatang (Santika, 2019). Penelitian deskriptif kualitatif ditujukan untuk mendeskripsikan dan menggambarkan fenomena-fenomena yang ada, baik bersifat alamiah maupun rekayasa manusia, yang lebih memperhatikan mengenai karakteristik, kualitas, keterkaitan antar kegiatan (Sukmadinata, 2011). Gejala sosial atau fenomena dalam penelitian ini adalah Pancasila semakin dilupakan dalam kehidupan berbangsa dan bernegara. Teknik 
pengumpulan data dalam penelitian kualitatif secara umum terdiri dari empat macam, yaitu observasi, wawancara, dokumentasi, dan gabungan atau triangulasi (Sugiyono, 2015). Dalam penelitian ini,metode pengumpulan data yang digunakan adalah studi dokumentasi dan literatur. Studi literatur yang dilakukan dengan mencari berbagai sumber tertulis, baik berupa buku-buku, arsip, majalah, artikel, dan jurnal, serta dokumen-dokumen yang dapat membantu peneliti dalam meninjau historis perjalanan Pancasila sejak penentapannya hingga reformasi

\section{HASIL PENELITIAN DAN} PEMBAHASAN

Setelah disahkan pada 18 Agustus 1945 Indonesia memiliki dasar negara bernama Pancasila sebagaimana dalam Pembukaan UUD 1945. Meskipun sudah sah menjadi dasar negara, Pancasila hanyalah sebuah ideologi yang belum berperan dan berjalan sebagaimana mestinya. Karena saat itu penjajah belum surut niatnya untuk kemabli menguasai Indonesia. Otomatis peran vital dan strategis Pancasila sebagai dasar negara yang sejak semula begitu didamba-dambakan bangsa Indonesia belum terwujud.

Kondisi seperti itu berlangsung cukup lama. Karena akibat politik devide et impera Belanda, Indonesia justru tercerai-berai dan pecah-belah menjadi sebuah negara serikat. Adapun landasan hukum perserikatan negara itu tertuang dalam Konstitui RIS 1949. Konstitusi ini juga memuat Pancasila, tetapi berbeda sekali dengan nilai-nilai Pancasila dalam UUD 1945. Tidak berlaku lama, akibat pergolakan rakyat yang menghendaki Indonesia kembali ke bentuk negara kesatuan, Konstitusi RIS 1949 pun akhirnya diganti dengan UUD Sementara 1950. Artinya peristiwa ketatanegaraan itu terjadi seiring dengan perubahan bentuk negara Indonesia dari serikat menjadi kesatuan. Rumusan Pancasila yang tertuang dalam UUD Sementara 1950 tiada bedanya dengan Konstitusi RIS. Dapat dikatakan, bahwa pada masa berlakuanya Konstitusi RIS Pancasila sedang tertidur lelap.

Konflik ideologis pendiri bangsa yang sempat mereda saat berjuang bersama mempertahankan kemerdekaan kemudian berlajut lagi setelah Indonesia berada di bawah UUD Sementara 1950. Pertarungan ideologis yang terjadi pada masa berlakunya UUD Sementara 1945 antara golongan nasionalis dengan golongan Islam akhirnya melahirkan Pancasila. Lewat Dekrit Presiden 5 Juli 1959, yang salah satu isinya memberlakukan kembali UUD 1945, menandakan Pancasila bangkit kembali dari tidurnya. Denan demikian, perdebatan yang berkepanjangan dan tidak berkesudahan menyangkut ideologi negara dalam persidangan Konstituante pada gilirannya dimenangkan oleh golongan nasionalis.

Setelah dibubarkannya Konstituante yang secara implisit didalamnya kembali memberlakukan Pancasila, mulailah babak baru perjalanan Pancasila dimasa Orde Lama dengan Presiden Soekarno sebagai motornya. Pancasila pada masa demokrasi 
terpimpin tidak memperoleh tempat sesuai dengan kedudukannya sebasgai dasar negara. Pancasila hanya menjadi penonton diluar arena politik, menyaksikan penguasa menjalankan kekuasaannya sesuka hati.

Banyak tindakan-tindakan penguasa yang justru bertentangan dengan ideologi Pancasila. Kebijakan-kebijakan Orde Lama kenyataannya justru menempatkan Pancasila sebagai ideologi yang tidak berfungsi dalam kehidupan berbangsa dan bernegara. Puncak dari penyelewengan Pancasila dimasa Orde Lama adalah pecahnya perang saudara atas nama perbedaan ideologi. Pada masa Orde Baru terjadi beberapa kasus yang cukup mencekam. Setelah sekian kali mengkhianti Indonesia dalam perjuangannya, lagi-lagi PKI berusaha mendorong revolusi untuk mengadakan kudeta berdarah. Adapun tujuan utamanya adalah untuk menggeser ideologi Pancasila yang rencananya akan digantikan dengan ideologi Komunis. Ide itulah yang mendorong meletusnya tragedi G30S/PKI yang dipimpin oleh D.N Aidit.

Peristiwa berdarah G 30 S/PKI itu menjadi titik balik yang mengakibatkan Soekarno lengser dari kekuasaannya. Tindakan menyimpang Soekarno terhadap Pancasila justru berbuah pahit. Tidak heran kemudian pada awal kepemimpinan Orde Baru, pemerintah mengusung jargon akan menjaga Pancasila. Kala itu Presiden Soeharto berjanji akan melaksanakan Pancasila secara murni dan kosekuen. Ke depannya pemerintahan yang dijalankan Orde Baru akan berdasarkan Pancasila dan
UUD 1945, sehingga cita-cita masyarakat adil dan makmur dapat terwujud.

Dalam perjalanannya, Pancasila yang merupakan hasil kristalisasi dari nilai-nilai luhur bangsa Indonesia, terus-menerus dikaji dan di kembangkan eksistensinya pada masa Orde Baru. Hal itu sesuai dengan janji awal Orde Baru yang akan menerapkan Pancasila dan UUD 1945 secara murni dan konsekuen. Semangat atau tekad Orde Baru dalam mempertahankan keberlangsungan Pancasila dalam kehidupan berbangsa dan bernegara diwujudkan melalui sistem pemerintahan yang meletakan dan menjunjung tinggi prinsip kekeluargaan dan gotong royong, yaitu sistem demokrasi Pancasila. Sayang demokrasi Pancasila hanya digunakan untuk membatasan kebebasan politik masyarakat. Misalnya demokrasi Pancasila diwujudkan dengan melakukan penyederhanaan yang memaksa partai politik masuk ke dalam tiga partai ini yaitu PDI, PPP, dan Golkar. Dengan alasan untuk menjaga ideologi. Pemerintah Orde Baru juga mengeluarkan kebijakan mengenai asas tunggal Pancasila, Asas tunggal Pancasila dikeluarkan agar seluruh organisasi masyarakat dan partai politik menggunakan Pancasila sebagai satusatunya asas. Berarti tidak ada ideologi lain, kecuali Pancasila dalam berorganisasi.

Tidak hanya dalam bidang politik, Orde Baru berupaya menginternalisasikan Pancasila melalui diseminasi ideologi yang disebut dengan P4. Orde Baru menggunakan P4 (Pedoman Penghayatan dan Pengamalan Pancasila) atau Ekaprasetia Pancakarsa sebagai usaha untuk membudayakan 
Pancasila dalam kehidupan berbangsa dan bernegara. Pada awalnya P4 memang memberi angin segar dalam pengamalan Pancasila, namun beberapa tahun kemudian kebijakan-kebijakan yang dikeluarkan justru bertolak belakang dan berlawanan dengan jiwa Pancasila.

Presiden Soeharto menggunakan istilah P4 untuk menacapkan kesan kuat, dalam benak rakyat, bahwa dirinya adalah seorang yang memegang teguh Pancasila. Dalam perjalananannya Pancasila ditafsirkan seenaknya sesuai selera maupun kepentingan kekuasaan pemerintah. Orde Baru menutup peluang bagi munculnya penafsiran lainnya. Demokrasi yang berlabel Pancasila yang didengung-dengungkan melalui P4 pada akhirnya tidak berjalan. dan pelanggaran HAM terjadi dimana-mana yang dilakukan oleh aparat pemerintah atau negara atas nama menjaga stabilitas dan kamtibmas berdasarkan Pancasila. Pancasila seringkali digunakan sebagai legimitator tindakan yang menyimpang. Sampailah kemudian pada upaya menempatkan Pancasila sebagai ideologi yang keramat. Pancasila kemudian dikeramatkan Orde Baru sebagai alasan untuk stabilitas nasional daripada sebagai ideologi yang memberikan ruang kebebasan untuk berkreasi.

Dalam berbagai kesempatannya Orde Baru berusaha membentuk opini, bahwa Pancasila dalam keadaan bahaya, sehingga memerlukan upaya ekstra keras untuk menjaganya agar jangan sampai diganti. Kemudian pada peringatan hari lahir Pancasila, 1 Juni 1967, Presiden Seharto menyampaikan pesan kepada seluruh bangsa Indonesia, bahwa, "Pancasila makin banyak mengalami ujian zaman dan makin bulat tekad kita mempertahankan Pancasila." Lebih lanjut Presiden Soeharto juga mengatakan bahwa Pancasila bukan dasar falsafah negara yang sekedar dikeramatkan dalam naskah UUD, melainkan Pancasila harus diamalkan.

Perlu diketahui, bahwa masa Orde baru merupakan masa pemerintahan yang terlama sepanjang sejarah ketatanegaraan di Indonesia. Di mana berkuasa selama kurang lebih 32 tahun mulai 1966 hingga tahun 1998 sebelum kemudian digantikan masa reformasi (Sila dkk, 2020). Pada masa kepemimpinan Orde Baru juga dapat dikatakan sebagai masa pemerintahan yang paling stabil. Di mana, stabilitas keamanan dan pembangunan serta merta selalu dikaitkan dengan keberadaan Pancasila sebagai dasar dan falsafah negara Indonesia.

Lebeling Pancasila dalam setiap tindakan penguasa, bukan berarti tidak ada penyimpangan terhadapnya (Nahudin, 2017). Penyimpangan-penyimpangan pun tetap berlangsung dan tidak dapat diabaikan begitu saja karena merugikan bangsa dan negara. Berikut ini adalah berbagai penyimpangan terhadap Pancasila yang dilakukan di bawah masa kepemimpinan Orde Baru:

$$
\begin{aligned}
& \text { 1. Pancasila yang kedudukannya } \\
& \text { sebagai dasar negara Indonesia } \\
& \text { tidak dilaksanakan secara murni } \\
& \text { dan konsekuen sesuai janjinya, } \\
& \text { yang terjadi adalah Pancasila }
\end{aligned}
$$


2. diredusir dengan makna yang tidak sesuai, disalahartikan arah dan tujuannya, serta disalah gunakan oleh Presiden Soeharto sebagai simbol untuk menjaga dan melanggengkan kekuasaan.

3. Pancasila dimanipulasi sebagai alat politik untuk menundukan dan menguasai rakyat. Sehingga pemerintah Orde Baru dapat dengan mudah melegitimasi setiap tindakannya yang melanggar dan menyimpang.

4. Pancasila yang diposisikan sebagai sumber nilai bangsa malah dibuat kabur (blurred) oleh banyaknya tindakan yang melanggar dan menyimpang. Saat itu segala bentuk kebijakan yang yang menyimpang bersembunyi dan berlindung dibalik fungsi pokok Pancasila. Otomatis siapapun yang berani menentang kebijakan Orde Baru sama saja menentang Pancasila.

5. Terjadi penyimpangan dan penyelewenangan terhadap asas kekeluargaan yang tertuang dan kandung di dalam Pancasila. Di mana Presiden Soeharto hanya mempercayakan kepada orangorang kepercayaannya untuk menguasai perusahaan besar yang sesungguhnya berada di bawah managemen negara. Pengelolaan sumber daya alam yang tidak benar telah menyuburkan praktikpraktik korupsi.

6. Demokrasi Pancasila yang selalu didengung-dengungkan Presiden Soeharto tidak pernah terjadi. Karena Presiden Soeharto dalam memimpin negara menggunakan cara-cara keotoritarian. Dengan demikian, semboyan Indonesia sebagai negara demokrasi yang mengutamakan rakyat, dari, untuk, dan oleh rakyat hanya sebuah kamuflase belaka untuk menutupi tindakannya yang sewenang-wenang.

7. Dengan alasan utama untuk mepersatukan bangsa Indonesia yang beragam, fungsi Pancasila justru disalahgunakan sebagai alat meleburnya heterogenitas dan perbedaan.

Berbagai tindakannya yang menyimpang terhadap Pancasila membuat Orde Baru harus menelah pil pahit (Halim, 2016). Sebab rakyat tidak tinggal diam dengan berbagai tindakan Pemerintah yang sewenang-wenang. Perlawanan rakyat Indonesia yang dimotori mahasiswa pada akhirnya membuahkan hasil (Santika, 2020). Karena pada tanggal 21 Mei 1998 adalah hari yasng sangat bersejarah. Dimana Presiden Soeharto mengumumkan pengunduran dirinya sebagai Presiden Indonesia. Munculah harapan, bahwa Pancasila akan lebih berfungsi pada masa reformasi. 
Namun apa yang terjadi malah sebaliknya, karena Indonesia memasuki era reformasi, Pancasila bukannya makin terhormat yang tampak seolah-olah terus tergerus dan semakin tenggelam (Meinano, 2016). Pancasila dalam pusaran sejarah masa lalu seakan-akan penuh dengan dosa. Sehingga banyak muncul anggapan, bahwa Pancasila tidak lagi relevan untuk diikut sertakan dalam dialektika kehidupan berbangsa dan bernegara.

Pancasila seolah terhapus dan hilang dari memori kolektif bangsa Indonesia (Sarjana, 2020). Efek samping pemerintahan Orde Baru yang menggunakan Pancasila sebagai alat pemukul, membuat setiap orang meninggalkan Pancasila. Pasca reformasi Pancasila semakin jarang diucapkan, dikutip, dibahas. Pancasila seperti tidak memperoleh tempat, baik dalam konteks kehidupan ketatanegaraan, kebangsaan, maupun kemasyarakatan (Sujana, 2016). Dalam kondisi seperti ini, Pancasila seperti tersandar sendirian di sebuah lorong sunyi senyap di tengah denyut kehidupan bangsa Indonesia yang semakin sibuk/hiruk-pikuk dengan politik demokrasi dan kebebasan berpolitik (Santika, 2019).

Berarti tidak mudah bagi bangsa Indonesia dalam menerapkan Pancasila, terutama dimasa reformasi yang dipenuhi dengan kebebasan dalam segala bidang kehidupan. Terlebih pada masa reformasi, penerapan Pancasila sebagai dasar negara dan pandangan hidup bangsa terus-menerus menghadapi berbagai tantangan. Memang penerapan Pancasila tidak lagi dihadapkan secara langsung pada ancaman pemberontakan-pemberontakan yang ingin mengganti Pancasila dengan ideologi lain, akan tetapi lebih dihadapkan pada kondisi kehidupan masyarakat yang diwarnai oleh kehidupan yang serba bebas.

Hal ini ditandai dengan adanya jaminan kebebasan setiap warga negara dalam berserikat dan berkumpul. Hal itu diwujudkan dengan membentuk organisasi. Sayangnya kebebasan itu kemudian di salahgunakan oleh sekelompok orang untuk merongrong ideologi Pancasila. Kemunculan HTI dierah reormasi secara terang-terangan menjadi penanda Pancasila dalam keadaan bahaya. Belakangan ini keberadaan HTI dianggap ancaman karena akan mengubah ideologi Pancasila (Santika, 2020).

\section{PENUTUP}

Pancasila kini semakin dilupakan, tidak hanya oleh masyarakat, tetapi juga dikalangan pemerintah. Seakanakan posisi Pancasila mulai tergeser dari hati bangsa Indonesia. Jika hal itu sampai terjadi, tidak tertutup peluang bangsa Indonesia akan terombang-ambing. Hal itu tidak terlepas dari rendahnya pemahaman bangsa ini terhadap Ideologi Pancasila tidak terlepas dari kelemahan Pendidikan Pancasila yang berlangsung selama ini. Tidak kalah pentingnya, bahwa kelemahan mendasar dalam pendidikan Pancasila adalah kurangnya pembahasan mengenai sejarah perjalanan Pancasila di Indonesia.

Setelah disahkan pada 18 Agustus 1945 
Indonesia memiliki dasar negara bernama Pancasila sebagaimana dalam Pembukaan UUD 1945. Meskipun sudah sah menjadi dasar negara, Pancasila hanyalah sebuah ideologi yang belum berperan dan berjalan sebagaimana mestinya. Konflik ideologis pendiri bangsa yang sempat mereda saat berjuang bersama mempertahankan kemerdekaan kemudian berlajut lagi setelah Indonesia berada di bawah UUD Sementara 1950.

Pancasila pada masa demokrasi terpimpin tidak memperoleh tempat sesuai dengan kedudukannya sebasgai dasar negara. Melalui berbagai kebijakannya, Orde baru menggunakan Pancasila sebagai justifikasi terhadap berbagai tindakannya yang salah. memasuki era reformasi, Pancasila bukannya makin terhormat yang tampak seolah-olah terus tergerus dan semakin tenggelam. Pancasila dalam pusaran sejarah masa lalu seakan-akan penuh dengan dosa.

\section{DAFTAR PUSTAKA}

Halim, Al. (2016). Posisi Ideologi Pancasila dalam Sistem K3tatangaraan: Suatu Kajian Filsafat. Seminar Nasional Hukum, 2 (1).

I Gede Sujana. 2016. Eksistensi Politik Hukum Perundang-Undangan dalam Sistem Ketatanegaraan Republik Indonesia. Jurnal Kajian Pendidikan Widya Accarya FKIP Universitas Dwijendra ISSN No. 2085-0018, (https://ejournal.undwi.ac.id, diakses 2 Januari 2021)

Meinarno, Eko. A dan Mashoedi, Sri Fatmawati. (2016). Pembuktiian
Kekuataan Hubungan Antara NilaiNilai Pancasila Dengan Kewarganegaraan. Jurnal Ilmiah Pendidikan Pancasila dan Kewarganegaraan.

Nahuddin, Yusuf Ekoo. (2017). Pemilihan Umum Dalam Sistem Demokrasi Perspektiif Sila Ke-4 Pancasila. Jurnal CakrawalaHukum, 8 (2).

Santika, I. G. N., Rindawan, I. K., \& Sujana, I. G. (2019). Memperkuat Pancasila Melalui Pergub No. 79 Tahun 2018 Dalam Menanggulangi Pengikisan Budaya Di Era Revolusi Industri 4.0. Prosiding Seminar Nasional Inobali 2019, 79, 981-990

Santika, I. G. N., Sujana, G., \& Winaya., M. A. (2019). Membangun Kesadaran Integratif Bangsa Indonesia Melalui Refleksi Perjalanan Historis Pancasila Dalam Perspektif Konflik Ideologis. Jurnal Etika Demokrasi (JED). 4 (2), 89-98. https://doi.org/10.26618/jed.v4i2.23 $\underline{91}$

Santika, I. G. N., Purnawijaya, I. P. E., \& Sujana, I. G. (2019). Membangun Kualitas Sistem Politik Demokrasi Indonesia Melalui Pemilu Dalam Perspektif Integrasi Bangsa Dengan Berorientasikan Roh Ideologi Pancasila. Seminar Nasional 1 Hukum dan Kewarganegaraan. 1 (1), 74-85. https://eproceeding.undiksha.ac.id/i ndex.php/semnashk/article/view/16 $\underline{65}$

Santika, I. G. N. (2019). Presidensialisme Dan Problematika Mekanisme Impeachment Presiden Dan/Atau Wakil Presiden Berdasarkan UUD 1945 Pasca Perubahan (Perspektif Pergulatan Hukum Dan Politik). Jurnal Ilmiah Ilmu Sosial. 5 (1), 23-34. http://dx.doi.org/10.23887/jiis.v5i1. $\underline{18777}$ 
Santika, I. G. N. (2020). Menggali dan Menemukan Roh Pancasila Secara Kontekstual. Jawa Tengah: Lakeisha.

Santika, I. G. N. (2020). Optimalisasi Peran Keluarga Dalam Menghadapi Persoalan Covid-19: Sebuah Kajian Literatur. Jurnal Ilmiah Ilmu Sosial. 6 (2), 127-137. http://dx.doi.org/10.23887/jiis.v6i2.284 $\underline{37}$

Santika, I Gusti Ngurah. 2017. Kepala Sekolah Dalam Konsep Kepemimpinan Pendidikan: Suatu Kajian Teoritis. Widya Accarya. 7 (1).

Santika, I. G. N. (2018). Strategi Meningkatkan Kualitas SDM Masyarakat Desa Padangsambian Kaja Melalui Pendidikan Karakter Berbasiskan Kepedulian Lingkungan Untuk Membebaskannya Dari Bencana Banjir. Widya Accarya. 9 (2).

Santika, I. G. N. (2020). Menelisik Akar Kegaduhan Bangsa Indonesia Pasca Disetujuinya Hasil Revisi UU KPK Dalam Perspektif Pancasila. Jurnal Ilmiah Ilmu Sosial. 6 (1), 6-36. http://dx.doi.org/10.23887/jiis.v6i1. $\underline{25001}$

Santika, I. G. N. (2021). Pendidikan Kewarganegaraan (Studi Komparatif Konstitusi Dengan UUD 1945). Jawa Tengah: Lakeisha

Santika, I. G. N. (2018). Strategi Meningkatkan Kualitas SDM Masyarakat Desa Padangsambian Kaja Melalui Pendidikan Karakter Berbasiskan Kepedulian Lingkungan Untuk Membebaskannya Dari Bencana Banjir. Widya Accarya. 9 (2).

Sila, I. M., Purana, I. M., \& Awa, A. R. B. (2020). Penerapan Nilai-Nilai
Pancasila Dalam Pelaksanaan Upacara Adat Purung Ta Kadonga Ratu Pada Masyarakat Desa Makatakeri Kecamatan Katikutana Kabupaten Sumba Tengah Provinsi Nusa Tenggara Timur (NTT). Widya Accarya. 11 (1). 84-96

Sugiyono. (2015). Metode Penelitian Pendidikan (Pendekatan Kuantitatif, Kualitatif, dan $R \& D$ ). Bandung: Alfabeta.

Sukmadinata, N.S. 2011. Metode Penelitian Pendidikan. Bandung: Remaja Rosadakarya 